Науковий вісник Львівського національного університету ветеринарної медицини та біотехнологій імені С.З. Гжицького

Scientific Messenger of Lviv National University of Veterinary Medicine and Biotechnologies

doi:10.15421/nvlvet8110

ISSN 2519-2701 print

ISSN 2518-1327 online

$\underline{\text { http://nvlvet.com.ua/ }}$

УДК 334.021.1

\title{
Державне регулювання сільського господарства в умовах активізації міжнародних інтеграційних процесів
}

\author{
О.С. Саламін, С.I. Поперечний \\ Oksana_Salamin@i.ua
}

Львівський національний університет ветеринарної медицини та біотехнологій імені С.3. Гжицького, вул. Пекарська, 50, Львів, 79010, Україна

\begin{abstract}
Розглядаються проблеми організаџії, спрямування та здійснення державної регуляторної політики в аграрному секторі економіки України. Показано особливості вітчизняного сільського господарства, через які не можуть автоматично застосовуватись поширені в економічно розвинутих країнах підходи до державного регулювання галузі. Основною з них $\epsilon$ неналежний рівень сформованості аграрного ринку та його інфраструктури, що призводить до високої мінливості иін. 3 а результатами здійсненого аналізу державного регулювання цін показано, щчо жоден з підходів, який застосовувався після 1991 року, не забезпечив належних результатів. В умовах активізачії міжнародних інтеграційних процесів проблеми посилюються обмеженням міжнародними організаціями держсавного впливу на ціну. Через високу мінливість иін прискорено розвиваються особливо великі за розмірами суб'єкти господарювання голдингового типу, зорієнтовані на виробництво сировинної продукції та ії поставки на зовнішній ринок, де ціни стабільніші. Зростання експортного потенціалу поєднується з посиленням монокультурної спрямованості вітчизняного сільського господарства, посиленням соціальних проблем у селах, значної ізолячії від ринків збуту малих і середніх за розмірами господарств. В иих умовах не відмічаються закономірні процеси диференціаиії особистих селянських господарств, трансформації їх у товарні господарства фермерського типу. Для забезпечення належної конкурентоспроможності переробленої продукиії сільського господарства пропонується формувати інтегровані системи з участю різних за розмірами суб' 'ктів господарювання, що займаються виробництвом, переробкою і збутом продукиії, а державну фінансову підтримку спрямовувати на ті інтегровані структури, які зорієнтовані на виробництво конкурентоспроможної на зовнішньому ринку продукиії. Необхідною умовою такої підтримки може бути розробка бізнес плану виробництва такої продукиії. Підтримку слід спрямовувати на придбання засобів виробництва, необхідних для реалізації бізне-плану. Для здійснення контролю за иілььовим характером витрачання коштів державної підтримки ї̈ слід здійснювати на засадах приватно-державного партнерства. Держава може залитатись власником засобів виробництва, придбаних за кочти державної підтримки до виходу на проектну потужність визначену бізнес планом. Після иього дані засоби можуть бути передані на баланси підприємств. Переваги такої підтримки порівняно з нинішньою полягають у ї̈ вищій результативності, спрямованості на реалізацію потенџіалу вітчизняного сільського господарства в умовах міжнародної інтеграції України. Позитивний досвід сприятиме поширенню інтегрованих систем на основі залучення децентралізованих коштів.
\end{abstract}

Ключові слова: державне регулювання сільського господарства, міжнародні інтеграційні процеси, державне регулювання иін, державна фінансова підтримка, системи державно-приватного партнерства.

\section{Государственное регулирование сельского хозяйства в условиях активизации международных интеграционных процессов}

\author{
А.С. Саламин, С.И. Поперечный \\ Oksana_Salamin@i.ua
}

Львовский национальный университет ветеринарной медицины и биотехнологий имени С.3. Гжицкого, ул. Пекарская, 50, г. Львов, 79010, Украина

Citation:

Salamin, O., Poperechnuy, S. (2017). State regulation of agriculture in the conditions of activation of international integration processes. Scientific Messenger LNUVMB, 19(81), 64-69. 
Рассматриваются проблемы организации, направления и осуществления государственной регуляторной политики в аграрном секторе экономики Украины. Показаны особенности отечественного сельского хозяйства, через которые не могут автоматически применяться распространены в экономически развитых странах подходы к государственному регулированию отрасли. Основным из них является ненадлежащчй уровень сформированности аграрного рынка и его инфраструктуpы, что приводит к высокой изменчивости цен. По результатам проведенного анализа государственного регулирования ценн показано, что ни один из подходов, который применялся после 1991 года, не обеспечил надлежащих результатов. В условиях активизации международных интеграционных прочессов проблемы усугубляются ограничением международными организациями государственного влияния на цену. Из-за высокой изменчивости цен ускоренно развиваются особенно большие по размерам субъекть хозяйствования холдингового типа, ориентированные на производство сырьевой продукиии и ее поставок на внешний рынок, где ијены более стабильны. Рост экспортного потенциала сочетается с усилением монокультурной направленности отечественного сельского хозяйства, усилением социальных проблем в селах, значительной изоляичи от рынков сбыта малых и средних по размерам хозяйств. В этих условиях не отмечаются закономерные прочессы дифференцииции личных крестьянских хозяйств, трансформации их в товарные хозяйства фермерского типа. Для обеспечения надлежащей конкурентоспособности переработанной продукции сельского хозяйства предлагается формировать интегрированные системы с участием различных по размерам субъектов хозяйствования, занимаюшихся производством, переработкой и сбытом продукции, а государственную финансовую поддержку направлять на те интегрированные структуры, которые сориентированы на производство конкурентоспособной на внешнем рынке продукции. Необходимым условием такой поддержки может быть разработка бизнес-плана производства такой продукичи. Поддержку следует направлять на приобретение средств производства, необходимых для реализации бизнес-плана. Для осуществления контроля за иелевым характером расходования средств государственной поддержки ее следует осуществлять на основе частно-государственного партнерства. Государство может оставаться собственником средств производства, приобретенных за средства государственной поддержки до выхода на проектную мощность. После этого данные средства могут быть переданы на балансы предприятий. Преимущества такой поддержки заключаются в ее высшей результативности, направленности на реализацию потенциала отечественного сельского хозяйства в условиях международной интеграчии Украины. Положительный опыт будет способствовать распространению интегрированньх систем на основе привлечения децентрализованных средств.

Ключевые слова: государственное регулирование сельского хозяйства, международные интеграционные проиессы, государственное регулирование иен, государственная финансовая поддержка, системь государственно-частного партнерства.

\title{
State regulation of agriculture in the conditions of activation of international integration processes
}

\author{
O. Salamin, S. Poperechnuy \\ Oksana_Salamin@i.ua
}

\begin{abstract}
Stepan Gzhytskyi National University of Veterinary Medicine and Biotechnologies Lviv, Pekarska Str., 50, Lviv, 79010, Ukraine
\end{abstract}

The problems of organization, direction and implementation of the state regulatory policy in agrarian sector of Ukrainian economy are described. The features of domestic agriculture are shown, through which the approaches to state regulation of industry cannot be automatically applied in economically developed countries. The main one is the inadequate level of formation of the agrarian market and its infrastructure, which leads to high variability of prices. The analysis of state regulation prices had been shown that none of the approaches applied haven't provide the proper results since 1991. The problems are aggravated by restrictions international organizations to state influence on the price. Due to the high variability of prices, especially large sized enterprises of the holding type are accelerating, focused on the production of raw materials and its supply to the external market, where prices are more stable. The growth of export potential is combined with an increase in the monoculture orientation of domestic agriculture, an increase in social problems in villages, a significant isolation from the markets for small and medium-sized farms. In these conditions, there are no regular processes of differentiation of private peasant farms, their transformation into farmer-type farms. In order to ensure the adequacy of the competitiveness of processed agricultural products, it is proposed to form integrated systems involving different sized enterprises engaged in the production, processing and marketing of products, and to direct state financial support to such integrated structures which are oriented towards to the production of competitive products. A prerequisite for such support may be the development of a business plan for the production of such products. Support should be directed to the acquisition of the means of production necessary for the implementation of the business plan. To exercise control over the price character of spending state support, it should be carried out on the principles of private-public partnership. The state may remain the owner of the means of production purchased with the state support until the project capacity is reached by a defined business plan. After that, these means can be transferred to the balance of enterprises, which was sent financial support. The advantages of such support compared to the existing ones are its higher efficiency, the focus on the implementation of the potential of domestic agriculture in conditions of international integration of Ukraine. Positive experience would be promote the deployment of integrated systems through decentralized funding.

Key words: state regulation of agriculture, international integration processes, state regulation of prices, state financial support, public-private partnership systems. 


\section{Вступ}

Актуальність проблем розробки та здійснення державної регуляторної політики в аграрному секторі економіки України обумовлена практичною значущістю та невідкладністю вирішення завдань становлення життєздатних, прийнятних як для засновників, так i для територіальних громад та суспільства загалом організаційних форм суб'єктів господарювання, забезпечення їх сталого розвитку, подолання безробіття у сільських населених пунктах. В умовах міжнародної інтеграції України особливої актуальності набувають проблеми аграрної політики, спрямованої на посилення конкурентоспроможності вітчизняної сільськогосподарської продукції та подолання сировинної орієнтації на зовнішньому ринку. Складність цих проблем поєднується 3 несформованістю загальноприйнятих навіть теоретичних підходів до їх вирішення.

Метою статті є обгрунтування доцільних напрямів удосконалення державного регуляторного впливу на суб'єкти господарювання в аграрному секторі економіки в умовах міжнародної інтеграції України. Для досягнення мети аналізувався стан сформованості аграрного ринку в Україні, вплив ціни як основного важеля ринкового регулювання на становлення суб'єктів господарювання за різними організаційно-правовими формами і розвиток окремих галузей, вивчались доцільні напрями державної підтримки сільського господарства та адаптації сільськогосподарських підприємств до міжнародних інтеграційних процесів.

\section{Матеріал і методи досліджень}

Об'єктом дослідження є економічні процеси державного регулювання сільського господарства в умовах міжнародної інтеграції України. Наукова гіпотеза дослідження базується на визнанні визначального впливу на суб'єкти господарювання ринкових важелів господарювання, спрямування державної аграрної політики на формування у значній мірі такого саморегуляційного ринкового середовища та життєздатних суб'єктів господарювання, які можуть реалізувати конкурентні переваги вітчизняного сільського господарства, а також забезпечити належний соціальний розвиток сільських територій. У процесі дослідження використовувались такі методи, як абстрактнологічний, економіко-статистичний, порівняльного аналізу.

\section{Результати та їх обговорення}

Наукові проблеми організації, здійснення та спрямування державної регуляторної політики в аграрній сфері перебувають в полі зору багатьох вчених економістів. Вони аналізуються у працях Григоренка Я.О., Сремєєва А.В., Клочко В.М., Коденської М.Ю., Мазура Г.Ф., Росохи В.В., Шарапи О.М., Юрченка А.Д. тощо. Значна увага до цієї проблеми поєднується 3 дискусіями навіть щодо стратегічних цілей державного регулювання сільського господарства. Часто пропонуються підходи, запозичені у зару- біжних виданнях. Сприяла цьому активізація міжнародних інтеграційних процесів - набуття Україною членства у СОТ і чинності угоди про асоціацію України та ЄС. При цьому не у повній мірі враховуються особливості вітчизняного сільського господарства, рівень сформованості ринкових відносин, досягнення оптимального поєднання регулювання ринковими важелями та регуляторного впливу органами управління сільським господарством. Необхідністю застосування таких же, як у більшості економічно розвинутих країн способів контролю безпечності продукції для забезпечення iï конкурентоспроможності на зовнішньому ринку обумовлено застосування схожого регуляторного впливу і на інші сфери діяльності в аграрному секторі економіки України. Не були реалізовані можливості асиметрії після набуття Україною членства у СОТ, відповідно до якої для нових членів цієї міжнародної організації у перші роки допускається більше можливостей державного регуляторного впливу, ніж для інших учасників. Характерною ознакою вітчизняних наукових досліджень проблем державного регулювання сільського господарства в Україні є їхня фрагментарність без належного системного підходу (Mazur, 2013). Аналізуються можливості державного впливу на збут продукції суб'єктами господарювання, державної підтримки сільського господарства, підтримки різних за розмірами та організаційними формами господарств (Kodenska and Yeremieieva, 2013; Hryhorenko, 2016; Yurchenko, 2016). 3 урахуванням визначального впливу ціни на економічні процеси особлива увага звертається на забезпечення паритетності цін на промислову та сільськогосподарську продукцію (Klochko, 2014). При цьому пропонується увесь спектр можливих підходів до вирішення проблеми - від невтручання у процеси ціноутворення 3 орієнтацією на визначальну саморегуляційну функцію ринку до забезпечення цінового паритету важелями прямого адміністративного впливу. Останнє аргументується зарубіжним досвідом такого державного впливу на рівень та співвідношення цін, зокрема досвідом США подолання негативних результатів глибокої депресії у 30-ті роки минулого століття проголошенням політики цінового паритету ядром усієї аграрної політики США. Намагання підтримання паритету цін в Україні у першій половині 90$\mathrm{x}$ років минулого століття призвело лише до підвищення загальних темпів інфляції. Безрезультатними були і періодичні намагання рішенням державних органів обмежити мінімально можливий рівень закупівельних цін. Такі намагання щодо застосування мінімально можливих цін на молоко призводили до скорочення обсягів закупівель і в наступні періоди до скорочення поголів'я корів та обсягів виробництва молока. До такого ж результату призвели намагання мінімізувати негативні результати загальної фінансової кризи обмеженням рентабельності господарської діяльності у сфері переробки молока та торгівлі соціально значущими молочними продуктами. Скорочення обсягів виробництва такої продукції та обсягів закупівель сировини для іï виробництва провокувало дефіцит продукції і подальше стрімке зростання роздрібних цін при втраті виробничого потенціалу як сіль- 
ського господарства, так і сфери переробки сільськогосподарської продукції. Вагомим негативним результатом була цінова нестабільність, адаптуватись до якої суб' єктам господарювання вкрай проблематично (табл. 1). При такій мінливості цін не можуть розроблятись не тільки стратегічні, а навіть поточні плани. Через високий ризик, як правило, не оформляються кредити. Втрачається стимулююче значення пільгово- го кредитування. Пряма державна фінансова підтримка лише частково компенсовує негативні результати впливу цінової нестабільності.

Пряма державна підтримка цінового паритету тривалий час не може здійснюватися через послаблення виконання цінами регулівної функції та неадекватне реагування виробниками на об'єктивні ринкові процеси, які проявляються у рівнях та динаміці цін.

Таблиия 1

Індекси цін реалізації продукції сільськогосподарськими підприємствами України у відсотках до попереднього року

\begin{tabular}{|l|l|l|l|l|l|}
\hline Продукція & 2012 p. & 2013 p. & 2014 p. & 2015 p. & 2016 p. \\
\hline Зерно & 109,1 & 90,8 & 132,8 & 156,6 & 119,0 \\
\hline Цукрові буряки & 82,4 & 92,1 & 122,1 & 160,5 & 105,9 \\
\hline Картопля & 47,6 & 146,4 & 112,3 & 79,9 & 104,9 \\
\hline Жива маса сільськогосподарських тварин & 86,7 & 125,0 & 106,5 & 120,8 & 126,1 \\
\hline Молоко & 117,4 & 104,8 & 118,6 & 167,5 & 83,5 \\
\hline
\end{tabular}

У жодній нині економічно розвинутій країні, поперше, не вдалося долати кризові явища у сільському господарстві лише здійсненням політики цінового паритету. По-друге, пряме державне втручання у процесі ціноутворення в даний час обмежується положенням СОТ як таке, що спотворює ринкові результати. Цінова стабілізація досягається не стільки державним регулюванням цін, скільки формуванням ринкового середовища та інфраструктури аграрного ринку, виконанням фізичними елементами, що відносяться до інфраструктури ринку таких основних функцій, як генерування товаропотоків і цін та стабілізації цін.

Загальнопоширеною у світі практикою уже на ранніх етапах становлення ринкових відносин було формування сільськогосподарськими виробниками збутових кооперативів. Цим вдавалося уникати монопольного впливу на ціни окремих закупівельних організацій, формувати порівняно великі товарні партії однорідної продукції і виводити їі на віддалені ринки. Створенням у таких кооперативах переробних підрозділів вдавалося формувати територіальні виробничі комплекси, у яких формуються прийнятні для усіх учасників ціни при мінімальному їх державному регулюванні. Альтернативним до цього загальнопоширеного напряму побудови аграрного ринку і розвитку сільського господарства є створення особливо великих за розмірами структур, які самостійно формують великі товарні партії і збувають їх на зовнішньому ринку. Їх розвиток забезпечується як значними інвестиціями, так і орієнтацією на стабільніші, порівняно 3 вітчизняними, ціни зовнішнього ринку, однак стале збільшення обсягів експорту сировини поєднується 3 посиленням соціальних проблем села.

На збільшення чисельності фермерських господарств за усі роки реформ спрямовуються організаційні зусилля органів управління сільським господарством та здійснюється пряма фінансова підтримка. Однак за останні роки намітилась стійка тенденція зменшення чисельності таких господарств. Не відмічається закономірної тенденції трансформації частини особистих селянських у фермерські господарства після внесень змін до Закону України «Про фермерські господарства», якими надано можливість створювати фермерські господарства сімейного типу без набуття ними статусу юридичної особи. Основна причина - неналежна сформованість інфраструктури аграрного ринку, проблематичність пошуку каналів розподілу на альтернативних засадах, неможливість уникнути монопольного впливу на ціну закупівельних організацій, висока мінливість закупівельних цін. Не забезпечило належних результатів спрямування державної регуляторної політики на активізацію процесів формування каналів розподілу на кооперативних засадах. Більшість створених таких кооперативів функціонує формально. Основна мета створення збутових кооперативів - уникнення монопольного впливу на формування закупівельних цін на продукцію. Державна фінансова підтримка переважно спрямовувалась на компенсацію 90\% вартості технічних засобів, придбаних молочарськими кооперативами, створеними для реалізації молока на молокозаводи за тими ж монопольними цінами, за якими у засновників заготовлялось молоко без створення кооперативу. Кооперативні канали дистрибуції продукції не забезпечували будь-яких переваг.

В умовах активізації міжнародних інтеграційних процесів необхідне суттєве підвищення конкурентоспроможності продукції. Без цього вона не тільки не може бути виведена на зовнішні ринки, а вітчизняні виробники через зростання імпорту втрачатимуть конкурентні позиції на внутрішньому ринку. Набуття Україною членства у СОТ дало поштовх зростанню обсягів експорту зерна, конкурентні переваги якого визначатимуться великими товарними партіями i низькою ціною продукції тваринницького походження. Низька ціна на продовольчі товари на зовнішньому ринку, як правило, не є визначальним чинником конкурентних переваг. Вагомішими є технічні параметри, які визначаються вимогами споживачів відповідних цільових сегментів ринку. Виробити та вивести на зовнішні ринки конкурентоспроможну продукцію тваринництва можна лише за умови узгодження вимог до ознак сировини, забезпечення належної технології як у сфері виробництва сировини, так і їі переробки, формування достатніх товарних партій продукції, систематичного дослідження ринку. Фермерські господарства можуть бути залучені до виробництва сировини, необхідної для виробництва конку- 
рентоспроможної на зовнішньому ринку продукції у складі кооперованих та інтегрованих систем. Інтеграторами таких систем переважно є переробні підприємства. Формуючи зони виробництва сировини з визначеними ознаками вони структуризують ринки, створюють спеціалізовані сировинні зони. Виникають кластерні формування підприємств, пов'язані спільним ланцюгом руху товарної маси. Дії таких підприємств узгоджуються та координуються. У результаті цього досягаються як цілі господарської діяльності кожного окремого учасника, так і загальні цілі аграрної політики держави, які полягатимуть у виробництві та виведенні на ринок конкурентоспроможної тваринницької продукції. 3 урахуванням цього на створення таких інтегрованих систем слід спрямовувати державну організаційну та фінансову підтримку.

У даний час державна фінансова підтримка має компенсаційний характер, не забезпечує належного розвитку галузей та підприємств, на які вона спрямовується. Доцільнішою є державна підтримка підприємств, які входять до складу інтегрованих структур, зорієнтованих на виробництві конкурентоспроможної продукції. Необхідною умовою такої підтримки може бути розробка бізнес-плану виробництва продукції. Підтримку слід спрямовувати на придбання засобів виробництва, необхідних для реалізації бізнес-плану. Для здійснення контролю за ціновим характером витрачання коштів державної підтримки іiї слід здійснювати на засадах приватно-державного партнерства. Держава може залишатись власником засобів виробництва, придбаних за кошти державної підтримки до виходу на проектну потужність, визначену бізнеспланом. Після цього дані засоби можуть бути передані на баланс підприємств, на які спрямовувалась фінансова підтримка. Переваги такої підтримки порівняно з нинішньою полягають у іiї вищій результативності, спрямованості на реалізацію потенціалу вітчизняного сільського господарства в умовах міжнародної інтеграції України. Позитивний досвід сприятиме поширенню інтегрованих систем на основі залучення децентралізованих коштів.

Переваги сільського господарства, організованого на засадах ринкової економіки проявляються лише за умови належної сформованості інфраструктури аграрного ринку.

Поняття ринкової інфраструктури є порівняно новим для вітчизняної економічної науки. Без особливих аргументів різні автори до складу інфраструктури ринку відносять різні елементи, нерідко й ті, які прямо не пов'язані з функціонуванням суб'єктів ринку банки, консалдингові організації, мости, дороги тощо. Одностайність представників різних точок зору полягає в тому, що до складу інфраструктури аграрного ринку слід відносити всі організації, що можуть виконувати посередницькі функції - оптові ринки сільськогосподарської продукції, біржі тощо.

В Україні розроблялась державна цінова програма розвитку оптових ринків сільськогосподарської продукції. На іï розвиток спрямовувалась державна фінансова підтримка. Все ж особливістю вітчизняних оптових ринків $є$ те, що вони створювались приватним капіталом. Метою їх діяльності є максимізація прибутку. Тому зусилля тут спрямовуються на надання послуг з реалізації продукції посередницьким комерційним структурам, які здійснюють комерційну діяльність на постійній основі, ніж виробникам сільськогосподарської продукції. Такі посередницькі комерційні організації часто пропонують імпортну продукцію. У перспективі існує реальна загроза перетворення таких ринків у логістичні центри імпортної продукції. Створення системи державно-приватного партнерства необхідне і на оптових ринках сільськогосподарської продукції. Державний капітал слід спрямовувати на залучення вітчизняних виробників продукції - надання транспортних послуг, створення філій ринків у сільських населених пунктах, де може зберігатись продукція і за дорученням виробників пропонуватись для реалізації. Централізовані фінансові кошти слід використовувати і для організації аукційних торгів, у яких прямо не зацікавлені власники ринків. Реалізуючи продукцію за результатами аукціонів у ранкові години виробники звільняються від потреби торгівлі нею протягом усього дня. Крім того, поширення інформації про ціни за результатами аукційних торгів впливатиме на рівень цін у інших каналах розподілу, обмежить можливості закупівельних організацій щодо монопольного маніпулювання цінами.

\section{Висновки}

Система державного регулювання сільського господарства в Україні дуже складна, фрагментарна, спрямована на вирішення багатьох проблем без чітко визначених стратегічних підходів. Таке регулювання здійснюється в умовах неналежного рівня сформованості аграрного ринку і його інфраструктури. Результатом цього $є$ висока мінливість цін, застосування способів їх регулювання, що не забезпечили очікуваних результатів, компенсаційний характер державної фінансової підтримки, яка лише частково послаблює проблеми, що періодично виникають, ізольованість від ринкових відносин невеликих суб'єктів господарювання, стійке скорочення чисельності фермерських господарств. В умовах активізації міжнародних інтеграційних процесів державну фінансову підтримку доцільно спрямовувати на розвиток інтегрованих структур і виробництво у них конкурентоспроможної на зовнішньому ринку продуктів.

\section{Бібліографічні посилання}

Hryhorenko, Ya.O. (2016). Osoblyvosti derzhavnoho rehuliuvannia ahrarnoho sektoru $\mathrm{v}$ konteksti zabezpechennia ekonomichnoi bezpeky derzhavy. Ekonomika APK. 7, 100-105 (In Ukrainian).

Klochko, V.M. (2014). Vplyv derzhavnoho rehuliuvannia ekonomiky na ekonomichni reformy krainy. Ekonomika APK. 1, 93-99 (in Ukrainian).

Kodenska, M.Yu., Yeremieieva, A.V. (2013). Derzhavna pidtrymka rozvytku ahrarnoho sektoru ekonomiky. Ekonomika APK. 6, 14-20 (in Ukrainian).

Mazur, H.F. (2013). Udoskonalennia mekhanizmu derzhavnoho rehuliuvannia ta stymuliuvannia 
rozvytku ahropromyslovoho vyrobnytstva. Ekonomika APK, 21-25 (in Ukrainian).

Rossokha, V.V., Sharapa, O.M. (2017). Upravlinnia zbutovoiu diialnistiu ahrarnykh pidpryiemstv $u$ transaktsiinomu vymiri. Ekonomika APK. 4, 67-76 (in Ukrainian).
Yurchenko, A.D. (2016). Derzhavne rehuliuvannia ahrarnoi sfery SshA. Ekonomika APK. 1, 92-99 (in Ukrainian).

Received 21.09.2017

Received in revised form 5.10.2017

Accepted 10.10.2017 